\title{
EVALUATION OF ENVIRONMENTAL ORDER LEVEL IN DISTRICTS OF KRAKOW METROPOLITAN AREA
}

\author{
Marta Szylar ${ }^{1}$ \\ Department of Spatial Development and Landscape Architecture, Faculty of Environmental Engineering and \\ Land Surveying, Hugo Kollataj University of Agriculture in Krakow, al. Mickiewicza 21, 31-120 Krakow, Poland, \\ e-mail: szylarmarta.kgpiak@gmail.com
}

Received: 2016.08.11

Accepted: 2016.09.26

Published: 2016.11.01

\begin{abstract}
Environmental order is one of sustainability aspects. Respect for environment, rational management of its resources and protection of biological diversity are only some of the rules that should be followed in order to preserve ecological balance. The paper is aimed to show evaluation of environmental order level in 7 districts included in Krakow Metropolitan Area (in polish: krakowski obszar metrolitalny - KOM). Such evaluations together with analyses of changes of environmental order factors (and also the remaining orders which are components of sustainability) enable to monitor effects of council unit's activities. Suggested analysis was performed on the basis of 18 factors of environmental order. The data were taken from the Local Data Bank [in Polish: Bank Danych Lokalnych (BDL)] and they concern 2014. The evaluation was carried out by classifying examined units to three types - with best average and worst preserved environmental order. This rating was made by means of two taxonomic methods - Wroclaw taxonomy and Thorndike's method. It was stated in the research that most districts do well with preserving environmental order. However, there are units where environmental balance is unsettled. They should take immediate actions in order to improve this situation. Collective activities within cooperation of KOM districts could also give measurable improvement and result in improving balance of the whole region's development.
\end{abstract}

Keywords: sustainability, environmental order, Wroclaw taxonomy, Thorndike's method, Krakow Metropolitan Area

\section{INTRODUCTION}

From the beginning, idea of sustainability paid close attention to protection and rational management of natural environment resources. By the time the demands concerning necessity to integrate social, economic and ecological activities appeared, progressive environment degradation caused among others by irrational using its resources, increase of problems connected with waste economy or finally progressive urban development were noticed. Awareness of serious consequences of development based only on consumption was a turning point for perception of the contemporary world.
The first document with global significance which paid attention to crisis in relationship of humans and environment was U'Thant's Report that was a speech record of The Secretary-General of the United Nations (UNSG) from 1969 [U'Thant 1969]. Based on statistical data, this report indicated dangers connected with global ecological crisis. Devastation of arable lands, uncontrolled agglomerative expansion, damage and decline of the next plant and animal species and also demographic explosion and connected with it restricting of unoccupied open areas were among other things regarded as the most dangerous phenomena. U'Thant called all countries to change attitude and make efforts to save and 
protect natural environment. The other important document that paid attention to finiteness of environmental resources as well as danger of global ecological catastrophe was published in 1972 report of Roman Club entitled Growth borders. Phrased there conception of ,zero growth” considering its radicalism was in a very short time replaced by „restricted growth" initiative concerning both demographic expansion slowing down and more rational exploitation of natural resources [Pawłowski A., Pawłowski L. 2008].

These documents entailed international as well as national actions [Batorczak 2013]. On the initiative of UNESCO, the programme „Man and the Biosphere" was started and continues to this day gathering over 650 Biosphere Reservations in 120 countries. The crucial event was also the conference organized in 1972 by the UN under the motto „We have only one Earth”, which was the first worldwide conference touching on natural environment problems. At that time, so called "the Stockholm Declaration" was accepted. The meeting agreed upon a document containing 26 principles to be obeyed by particular countries for protecting environment both individually and collectively. Consequently, United Nations Environmental Programme (UNEP) came into existence. Also in Poland, a public administration department that dealt with this topic came into being. At first, it was called the Polish Committee of Human Environment Protection transformed later into the National Council of Environment Protection.

However, with reference to sustainability, the document issued in 1987 and entitled „Our Common Future" was the most significant. This report was presented by the Global Commission for Environment and Development which was constituted in 1983 by the UN. Constant and sustainable development being the central point of that document was determined as a social and economic development which allows to provide needs of contemporary and future generations with respect for the environment [Mazur-Wierzbicka 2005].

With reference to the environmental order, the most important event was the $2^{\text {nd }}$ United Nations Conference on Environment and Development (UNCD) organised in 1992. Two documents were accepted during this conference. The first one was „The Declaration from Rio concerning environment and development" which included a list of rights and duties of every signatory country in order to provide sustainability and good life condi- tions. The second document was Agenda 21 that includ recommendations aimed at protection and forming of human life environment, protection of natural resources and also sustainable production and consumption. Reference to activities on every organizational level - from global to local - was a significant advance because each of them needs realization of different tasks. Necessity to create so called local Agendas 21 which were reflections of the rules of that document on local levels was indicated [www.agenda21.waw.pl].

Implementing all rules and activities determined in above-mentioned documents and declarations needs continuous monitoring of sustainability level of particular territorial units. To this end, proper factors are worked-out to measure and determine changes, that take place in social, economic and environmental development of the given units [www.sas24.org]. Evaluation of the current state allows self-government authorities to take activities necessary to preserve and improve sustainability in order to achieve the ideal model, where all aspects of unit's functioning are kept in balance. So sustainability factors are informational and diagnostic tools which help to monitor development stages on local, regional and national levels. The choice of proper factors is basic to precise and real evaluation of that development. Sustainability conception allows to distinguish its four basic aspects: social order, economic order, environmental order and institutional and political ones [Czarski 2011].

The present paper is aimed at determination of sustainability level in districts which are included in Krakow Metropolitan Area (KOM) borders. Taking into account criteria on the basis of which KOM borders were determined, factors that concern social and economic development of this region were analysed most often [Raźniak 2012]. However, because of Krakow city influence on surrounding rural areas, taking care of natural environment in such a way that suburbanization processes would not cause damage of nature resources and natural landscape seems to be particularly important. First and foremost, presented analysis should show the way of monitoring the environmental order state (and also the other orders being components of sustainability). Such researches allow to estimate levels of particular aspects on the basis of the other self-government units and in consequence - to compare effectiveness of actions led by these units. 


\section{MATERIALS AND METHODS}

Districts that are part of Krakow Metropolitan Area including one municipal district: Krakow city and also 6 land districts: Bochnia, Krakow, Miechow, Myslenice, Proszowice and Wieliczka were the subject matter of researches (Fig. 1). KOM is one of 5 Malopolska Province subregions. Legal basis for creating that subregion was the Act from $27^{\text {th }}$ March 2003 on Spatial Planning and Development. This Act defines the metropolitan area as: "an area of a big city and direct surroundings functionally connected with it, appointed in spatial conception of country development". Creating KOM was aimed at maintaining and growth of this area competitiveness and in consequence also Malopolska Province against a backdrop of the country and in the international arena [Sowa M. 2007]. As districts union, KOD was intended for tasks in the range concerning among others growth and spatial development, undertakings of infrastructural character, limiting of spatial and economic conflicts, as well as monitoring changes that take place in this area in spatial, social, economic and business aspects. At first, being guided by criteria such as commuting, population density or initiative level, KOM borders included 51 communes situated in 8 districts. Current delimitation was performed to establish Malopolska Province Development Strategy for 2011-2020 involving 7 districts

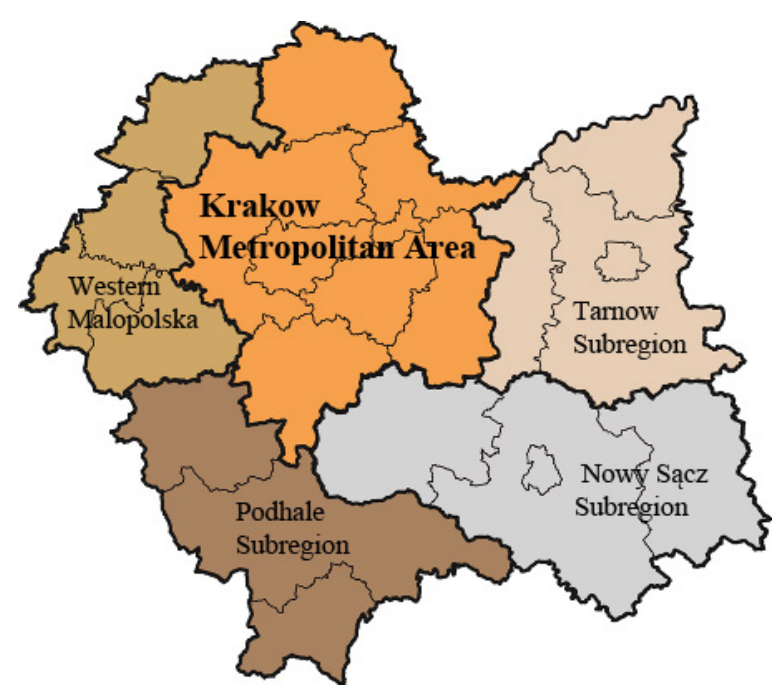

Figure 1. Krakow Metropolitan Area against the background of Malopolska Province partition to functional subregions [on the basis of Subregional Development Programme to 2020 (Project)] which are the subject matter of this elaboration in Krakow Metropolitan Area borders.

Environmental order is one of four orders distinguished in sustainability concept. In the elaboration of Central Statistical Office of Poland [Czarski 2011], 24 national factors which describe environmental order divided into 8 topic areas were specified. Due to data availability, 18 factors divided into 6 topic areas were used in the presented analysis (Tab. 1).

Table 1. Environmental order factors

\begin{tabular}{|c|c|}
\hline \multicolumn{2}{|c|}{ Waste economy } \\
\hline $\mathrm{X} 1$ & $\begin{array}{l}\text { Amount of mixed municipal waste from house- } \\
\text { holds collected during a year for } 1 \text { inhabitant in } \\
\text { general }[\mathrm{kg}]\end{array}$ \\
\hline $\mathrm{X} 2$ & $\begin{array}{l}\text { Purified municipal and industrial wastewater in } \\
\text { relation to municipal and industrial wastewater that } \\
\text { needs purifying in general [\%] }\end{array}$ \\
\hline $\mathrm{X} 3$ & $\begin{array}{l}\text { Amount of individual wastewater treatment plants } \\
\text { in general [items] }\end{array}$ \\
\hline $\mathrm{X} 4$ & Wild waste sites [item $/ 100 \mathrm{~km}^{2}$ ] \\
\hline $\mathrm{X} 5$ & Wild waste sites $\left[\mathrm{m}^{2} / 100 \mathrm{~km}^{2}\right]$ \\
\hline \multicolumn{2}{|c|}{ Air protection } \\
\hline $\mathrm{X} 6$ & $\begin{array}{l}\text { Air pollution emission from especially burdensome } \\
\text { factories (gas ones) [t/r] }\end{array}$ \\
\hline $\mathrm{X} 7$ & $\begin{array}{l}\text { Air pollution emission from especially burdensome } \\
\text { factories (dust ones) [t/r] }\end{array}$ \\
\hline X8 & $\begin{array}{l}\text { Share of pollutants caught or neutralized in de- } \\
\text { vices for pollutants reduction in especially burden- } \\
\text { some companies in the whole of created pollutants } \\
\text { (gas ones without CO2) [\%] }\end{array}$ \\
\hline X9 & $\begin{array}{l}\text { Share of pollutants caught or neutralized in de- } \\
\text { vices for pollutants reduction in especially burden- } \\
\text { some companies in the whole of created pollutants } \\
\text { (dust ones) [\%] }\end{array}$ \\
\hline \multicolumn{2}{|c|}{ Climat changes } \\
\hline $\mathrm{X} 10$ & $\begin{array}{l}\text { Emission of carbon dioxide from especially bur- } \\
\text { densome companies in total }[t / r]\end{array}$ \\
\hline X11 & $\begin{array}{l}\text { Communes expenses at atmospheric air and } \\
\text { climat protection per } 1 \text { inhabitant in total [\%] }\end{array}$ \\
\hline \multicolumn{2}{|c|}{ Energy } \\
\hline $\mathrm{X} 12$ & $\begin{array}{l}\text { Usage of electricity per } 1 \text { inhabitant in general } \\
\text { [kWh] }\end{array}$ \\
\hline $\mathrm{X} 13$ & Usage of electricity per 1 city dweller [kWh] \\
\hline $\mathrm{X} 14$ & Usage of electricity per 1 country dweller [kWh] \\
\hline \multicolumn{2}{|c|}{ Biodiversity } \\
\hline X15 & $\begin{array}{l}\text { Participation of legally protected areas in total area } \\
{[\%]}\end{array}$ \\
\hline $\mathrm{X} 16$ & Participation of green lands in total area [\%] \\
\hline \multicolumn{2}{|c|}{ Lands usage } \\
\hline $\mathrm{X} 17$ & Intensity of afforestation [\%] \\
\hline $\mathrm{X} 18$ & Woodiness [\%] \\
\hline
\end{tabular}

Source: own elaboration on the basis of Local Data Bank 
Values of particular factors were collected from the website of the Local Data Bank (BDL). In the module that concerns sustainability factors there is possible to generate statistical data on the local and regional levels. Values of particular factors of environmental order concern 2014.

Choice of the proper method of objects classification causes some difficulties. Walesiak [2004] mentions four principal approaches to this problem. One of them is based on using several evaluative methods and then comparison and estimation of compatibility of their results on the basis of contingency table that is cross classification of two divisions results. After studying several evaluative methods, two taxonomic methods: the Wroclaw taxonomy and the Thorndike's method were finally used for the analysis.

The Wroclaw taxonomy belongs to dendrite methods also called in literature graph methods. It is classified as one of hierarchical procedures, in other words these in which disjunctive aggregations of the first row will be included in groups of the higher row showing full information regarding classification structure [Grabiński 1992]. Dendrite's building stage (coherent and open graphs) can be described as agglomerative procedure. The analysis and creating on that basis separate types can be included into divisional procedures [Grabiński et al. 1989]. In dendrite methods, taking rules and concepts from graphs theory to present classification results makes perfect sense. First, it gives theoretical bases to every method of that group and secondly it provides useful and simple description language as well as simplifies interpretation of results [Nowak 1990]. For the first time, the Wroclaw taxonomy was used for anthropology purposes [Florek et al. 1951]. Elaboration of this method by a group of mathematicians from the Wroclaw University under the leadership of Hugo Steinhaus is considered to be one of the crucial achievements of Polish school of taxonomy [Jajuga et al. 2015]. One of the greatest advantages of this method is possibility to illustrate complicated relations between objects and also clear presentation of classification results. However, attention is paid to great labour consumption of the method as well as technical problems with presenting the results when the number of objects is bigger $(>30)$ [Prus, Szylar 2015].

The Thorndike's method is one of area evaluative ones. The basis of every method in this group is to divide the evaluative area into deter- mined subareas according to the rules accepted in the beginning. Objects located in these subareas are treated as separate clusters. Subareas are called hypercubes or hyperspheres [Grabiński 1992, Grabiński et al. 1989, Kolenda 2006]. The most often way to set out radiuses (or edges) of subsets is usage of the formula (1.1):

$$
d_{0}=\max _{i} \min _{j}\left\{d_{i j}\right\}(i, j=1, \ldots, n),
$$

where: $d_{i j}$ - distance matrix elements;

$n$ - number of classified objects,

$i, j$ - the number of data matrix row and column.

The size of radius is crucial for classification results, particularly if grouped together objects demonstrate significant similarity. Then, even the slightest change of the radius's size can significantly influence obtained results. Creating different-size groups, therein one-element groups and rare clusters that contain most objects can be ranked to the greatest disadvantages of area methods.

Initial activities to be performed were similar to both used taxonomic methods. First, diagnostic features, in other words, these which describe environmental order issues best, should have been chosen from owned statistical data set. The choice was made on the basis of correlation matrix. It was considered that every of 6 topic groups should be represented by one feature. Features regarded as diagnostic ones should be characterized by the highest correlation possible in their topic groups and be the lowest correlated with the remaining diagnostic features. These conditions guarantee that the chosen features will include the broadest resource of information from their topic area and simultaneously they will not copy data from the other areas. On that basis, the following data were selected to further analysis: X5 (Wild waste sites $\left[\mathrm{m}^{2} / 100 \mathrm{~km}^{2}\right]$ ), $\mathbf{X 9}$ (Share of pollutants caught or neutralized in devices for pollutants reduction in especially burdensome companies in the whole of created pollutants (dust ones) [\%]), X10 (Emission of carbon dioxide from especially burdensome companies in total $[\mathrm{t} / \mathrm{r}]$ ), X13 (Usage of electricity per 1 city dweller [kWh]), X15 (Participation of legally protected areas in total area [\%]), X18 (Woodiness [\%]).

Data standardization was made by means of zero unitarisation procedure (1.2.) [Walesiak 2004]: 


$$
z_{i j}=\frac{x_{i j}-\min _{i}\left\{x_{i j}\right\}}{r_{j}}
$$

where: $x_{i j}-$ value of $j$-th variable in $i$-th object, $z_{i j}$ - normalized value $X_{i j}$,

$r_{j},-$ range set on the basis of $j$-th variable's value.

Usage of that procedure's main advantage is that all obtained variables' values are positive and they are located in the range of $<0-1>$. The last step common for both procedures was creating the distance matrix. Euclidean distance was used to calculate this matrix. Further calculations were performed separately for every procedure.

In the Wroclaw taxonomy, assignation of objects most similar to each other in order to create a dendrite is estimated. It means that on the basis of the taxonomic distances matrix, is possible to find the closest neighbour for every object (district). It is assumed, that the shortest distance between objects testifies to the largest similarity between them. Then on the base of such statement, the dendrite should be built by joining nodes (objects) with edges of proper length. If created in such a way graph is an incoherent one - more than one cluster is formed - links between created clusters should be searched. It is performed as before with the assumption that single objects are replaced by clusters. Resemblance in between this clusters is determined on the basis of the shortest distances between objects in two different clusters. The procedure is repeated until receiving a coherent graph.

In the Thorndike's method, maximal number of iterations and finally created number of clusters should be determined at the beginning. Then, the algorithm presumes the choice of the most distant objects which are intended to be centres of two first groups. If demanded number of clusters is bigger than 2, then the centre of the next clus- ter which should be the most distant from already stated clusters' centres is appointed. Procedure is repeated until the demanded number of groups is obtained. Objects that are not centres are assigned to their closest centre. Next, elements between clusters are moved to find their most optimal location according to the accepted formula [Grabiński et al. 1989]. If the next displacements do not follow or the assumed maximum iterations number is achieved, the procedure is finished.

\section{RESULTS AND DISCUSSION}

The taxonomic procedures taken in the research were used to create groups of similar districts. In every stated type there are districts that show significant similarity, taking environmental order factor into consideration.

Within the frames of the Wroclaw taxonomy and according to presented earlier description, the statement of the districts and their closest neighbours together with the distances between these objects was created on the basis of the distance matrix (Table 2).

In second place, on the basis of the Table, the dendrite was created (Fig. 2). As this dendrite turned out to be a coherent graph (all classified elements belong to one cluster), the procedure was finished. Numbering of particular districts responds to the ordinal number from Table 2.

Assignation of types of districts similar due to environmental order factors comes down to removing of the longest connections from the dendrite which corresponds with the longest distances between objects. To create three clusters, two longest edges should be removed. In the presented example, there are the edges joining object No. 4 (Miechow district) with No. 6 (Proszowice district) as well as No. 1 (Krakow city district)

Table 2. Specification of districts together with their closest neighbours

\begin{tabular}{|c|c|c|c|}
\hline No. & District & $\begin{array}{c}\text { The shortest } \\
\text { distance }\end{array}$ & The closest neighbour \\
\hline 1 & Krakow city district & 1.206 & Wieliczka district (7) \\
\hline 2 & Bochnia district & 0.840 & Myslenice district (5) \\
\hline 3 & Krakow district & 0.880 & Bochnia district (2) \\
\hline 4 & Miechow district & 0.921 & Bochnia district (2) district (2) \\
\hline 5 & Myslenice district & 0.840 & Miechow district (4) \\
\hline 7 & Proszowice district & 1.144 & Myslenice district (5) \\
\hline
\end{tabular}




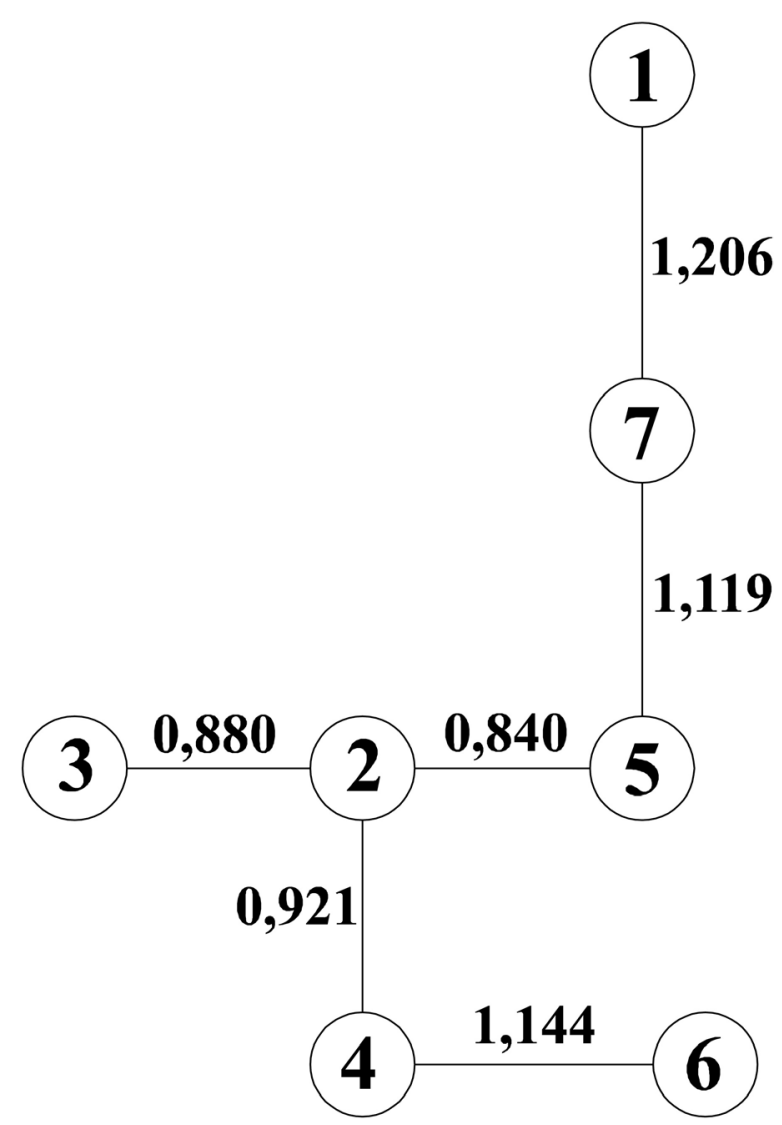

Figure 2. Coherent graph

with No 7 (Wieliczka district). In that way, the following division will be achieved:

Type $I=\{1\}=\{$ Krakow city county $\}$

Type $I I=\{6\}=\{$ Proszowice county $\}$

Type III $=\{2,3,4,5,7\}=\{$ Bochnia $c$., Krakow c., Miechow c., Myslenice c., Wieliczka c.\}

In the Thorndike's method, Numerical Taxonomy programme was used to perform calculations [Kolenda 2006]. The set's division into 3 clusters was assumed - like in the Wroclaw taxonomy. The option max min which presumes that a centre of the closest cluster is the point with the greatest of minimal distances from all already existing clusters' centres was used to determine the next and most distant from already existing centres. Such classification is illustrated by the graph below (Fig. 3).

Obtained classification presumes the following division into types:

Type $I=\{1\}=\{$ Krakow city county $\}$

Type $I I=\{6,7\}=\{$ Proszowice c., Wieliczka c. $\}$

Type III $=\{2,3,4,5\}=\{$ Bochnia $c$., krakow c., Miechow c., Myslenice c.\}

It is easy to observe that results of both performed classifications do not differ significantly from each other. Only Wieliczka district was clas- sified to two different types: in the Wroclaw taxonomy to type III while in the Thorndike's procedure to type II. Performing division to types in the Wroclaw taxonomy, the longest edge of the dendrite can be eliminated (creating 4 types instead of 3). Wieliczka district could create then the next one-element group. It shows its greatest distance from the remaining objects in type III. Likewise, if in the Thorndike's procedure creating 4 types was presumed - type II would be divided into two one-element groups.

To evaluate environmental order level of appointed districts' types, their assessment should be performed. It means that on the basis of diagnostic data accepted for analysis, it should be determined which of the types is the best and which one is the worst from the environmental order's point of view. It was assumed that features X9, $\mathrm{X} 15$ and $\mathrm{X18}$ are stimulants also known as positive features from the viewpoint of the tested phenomenon, whereas features X5, X10 and X13 are destimulants or negative features with reference to the tested order. Analyzing rankings created on the base of diagnostic features' values it can be noticed that Proszowice district takes the last place with reference up to two features regarded as stimulants - $\mathbf{X 9}$ and $\mathbf{X 1 8}$. Wieliczka district is considered to be the worst taking features X13 and X15 into consideration. Therefore, it can be presumed that in both classifications type II is the one with the worst protected environmental order. It also suggests that the Thorndike's method which assigned Proszowice and Wieliczka districts to one type turned out to be more accurate and reflecting reality better. Although Krakow city district receives good places as regards features X5 and $\mathbf{X 9}$, in the other cases it takes much further positions. Therefore, type I can be described as the one with averagely preserved environmental order. According to the ranking's analyses for the

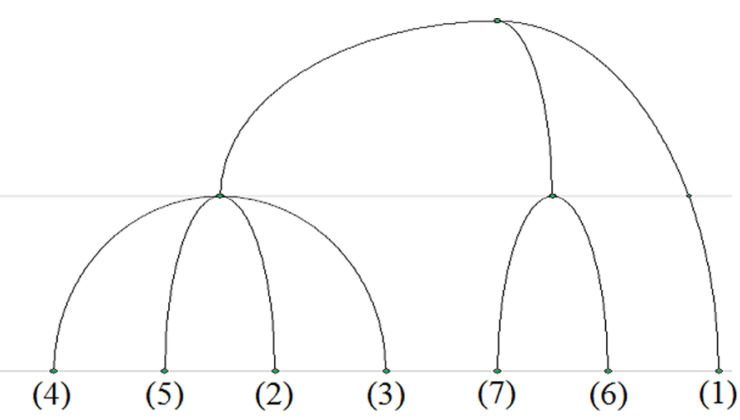

Figure 3. Resultative graph on the basis of Thorndike's method 
remaining districts, type III is the one with the best preserved environmental order.

The final result of the analysis is presented in Fig. 4 which illustrates classification effect by means of the Thorndike's method with districts distribution into types with the best, average or worst preserved environmental order.

Evaluation performed on the basis of the presented above analysis clearly indicates that among districts of Krakow Metropolitan Area Proszowice and Wieliczka districts are the ones with the worst preserved environmental order. The average rating is received by Krakow city. Balance in the range of environmental order is maintained in Bochnia, Krakow, Miechow and Myslenice districts. On that basis it can be concluded that Krakow authorities try to carry out actions to protect and improve natural environment's state. Despite socio-economical character of the city which is the centre of described agglomeration, environmental issues are taken into account here. Lack of wild waste sites, significant expenses at air protection as well as green lands percentage in the total city area can be definitely regarded as positive aspects. However, taking air pollution or carbon dioxide emission from especially burdensome companies into account, it seems necessary to introduce actions aimed at these factors values' improvement. The worst situation is in Proszowice and Wieliczka districts. In contrast to Krakow

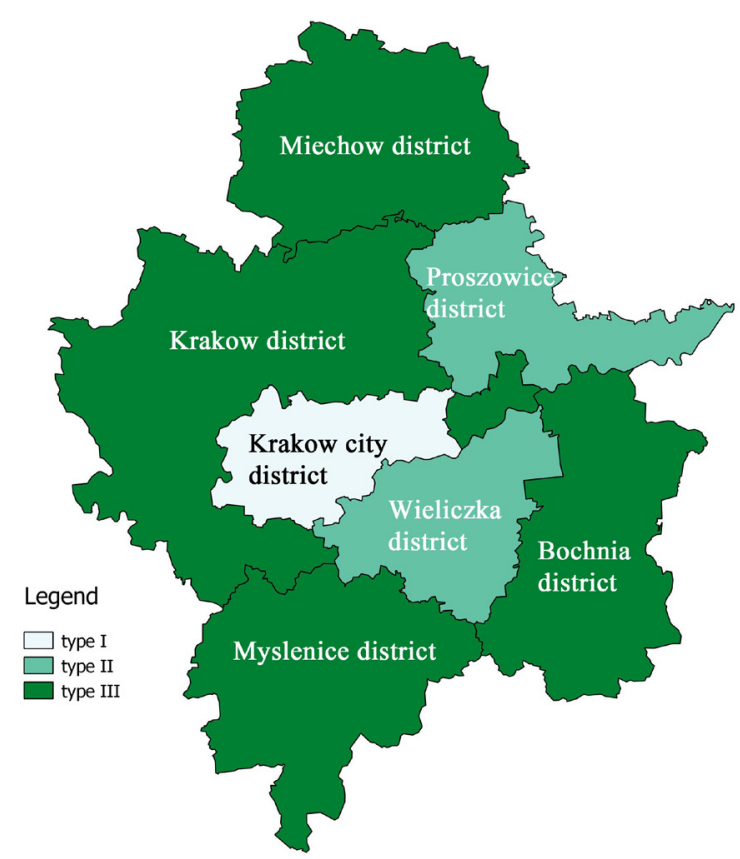

Figure 4. Classification of KOM districts by means of the Thorndike's method according to types city, emission of carbon dioxide from especially burdensome companies is low in these districts, however in terms of the remaining environmental order factors they do much worse. Rural communes being matched with rustic landscape and life appear to care significantly less for conservation of environmental balance. These district's authorities should undertake immediate actions in order to improve that situation. Cooperation with the other districts within the framework of KOM union would be recommended in this case. Introducing of integrated actions in favour of environmental order improvement would certainly support the whole region's sustainability.

\section{CONCLUSIONS}

Environmental order has always had specific significance in sustainability meaning. This is due to the fact that there were negative changes occurring in natural environment which actually paid attention to necessity of keeping balance both in local units and the whole world development.

To preserve environmental order and also improve its level where it is not maintained, several actions should be taken. Monitoring of changes of this order factors' values is necessary especially in case of introducing new programmes and strategies and summing up the finished ones. For it is important to control activities being conducted. Checking in which way specific decisions influenced environmental order as a whole will allow to avoid mistakes consisting in improvement of some aspects with worsening or negligence of the others. In order to talk about sustainability accomplishment, the results of such analyses should be referred to social and economic orders as well. Many disciplines within the limits of which sustainability is researched are closely connected with the Earth factors [Matuszczak 2009].

The analysis presented above is the attempt to evaluate environmental level in the districts of Krakow Metropolitan Area. Similar evaluations can be performed in order to indicate units which should take up broader activities to preserve environmental, social or economic order. They would as well help to point the topic fields authorities of tested areas should focus on. Activities taken up on the basis of similar analyses should bring the tested areas closer to sustainability ideal model. 


\section{REFERENCES}

1. Batorczak A. 2013. Education for Sustainable Development in Poland and Great Britain (PhD dissertation) (In Polish: Edukacja dla Zrównoważonego Rozwoju w Polsce i w Wielkiej Brytanii). University of Warsaw Faculty of Education. http://depotuw.ceon.pl [access: 12.10.2015]

2. Czarski E. [red.] 2011. Sustainable Development Indicators for Poland (In Polish: Wskaźniki zrównoważonego rozwoju Polski.). Central Statistical Office. Katowice

3. Florek K. at al. 1951. Wroclaw taxonomy (In Polish: Taksonomia wrocławska). Anthropological Review. 193-211

4. Grabiński T. 1992.Taxonomy methods. Laboratory of Research and Teaching Assistance (In Polish: Metody taksonometrii). Cracow University of Economics. 101-102, 113

5. Grabiński T., Wydymus S. Zeliaś A. 1989. Methods of numerical taxonomy in socio-economic phenomena modelling (In Polish: Metody taksonomii numerycznej w modelowaniu zjawisk społecznogospodarczych). Polish Scientific Publishers. Warsaw. 67, 71, 76-77 (In Polish)

6. Jajuga K. in. 2015. XXV years of SKAD (In Polish: 25 lat SKAD). Taxonomy 24. Classification and Data Analysis - Theory and Applications. Research Papers of Wroclaw University of Economics. No. 384. 15-24

7. Kolenda M. 2006. Numerical Taxonomy. Classification, Ranking and Analysis of Multivariable Objects (In Polish: Taksonomia numeryczna. Klasyfikacja, porządkowanie i analiza obiektów wielocechowych). Publisher: Oscar Lange University of Economics in Wroclaw. 95, 257

8. Matuszczak A. 2009. Conception of sustainable development in economic, environmental and social space (In Polish: Koncepcja zrównoważonego rozwoju w obszarze ekonomicznym, środowiskowym i społecznym). Annual journals of Kuyavian-Pomeranian Academy in Bydgoszcz. No 2. 125-141

9. Mazur-Wierzbicka E. 2005. The concept of sustainable development as the basis for management of the natural environment (In Polish: Koncepcja zrównoważonego rozwoju jako podstawa gospodarowania środowiskiem przyrodniczym). The functioning of the Polish economy in the conditions of integration and globalization. 33-44
10. Nowak E. 1990. Taxonomic methods for socioeconomic object classification (In Polish: Metody taksonomiczne w klasyfikacji obiektów społecznogospodarczych). National Economic Publishing House. Warsaw. 69-70

11. Pawłowski A., Pawłowski L. 2008 Sustainable development in contemporary civilisation. Part 1: The environment and sustainable development (In Polish: Zrównoważony rozwój we współczesnej cywilizacji. Część 1: Środowisko a zrównoważony rozwój). Problems of Sustainable Development. Vol. 3. No 1. 53-65

12. Prus B., Szylar M. 2015. Evaluation of possibility to use typological procedure and Wroclaw taxonomy to analyse agriculture development conditions on the example of the former Kraków Voivodship communes. Geomatics, Landmanagement and Landscape. No.4. 83-101

13. Raźniak P. 2012. Socio-economic processes in Krakow Metropolitan Area (In Polish: Procesy społeczno-ekonomiczne w Krakowskim Obszarze Metropolitalnym). Geographical Studies. No. 129. 63-81

14. Sowa M. 2007. Development of the metropolitan functions of Krakow Metropolitan Area (In Polish: Rozwój funkcji metropolitalnych Krakowskiego Obszaru Metropolitalnego) http://www.malopolskie.pl [access: 29.01.2016]

15. Subregional Development Programme for 2020. 2015. Krakow (In Polish: Subregionalny Program Rozwoju do roku 2020 (projekt). 2015. Kraków)

16. U'Thant. 1969. Report of the UN Secretary-General. Human Problems of the Human Environment (In Polish: Raport Sekretarza Generalnego ONZ z dnia 26.05.1969 r. Człowiek i jego środowisko). Newsletter of Polish Committee for the UNESCO $1 / 1969$

17. Spatial Planning and Land Development Act of 27 March 2003 (In Polish: Ustawa z dnia 27 marca 2003 r. o planowaniu i zagospodarowaniu przestrzennym). Dz.U. 2003 nr 80 poz. 717

18. Walesiak M. 2004. Decision problems in a cluster analysis procedure (In Polish: Problemy decyzyjne w procesie klasyfikacji zbioru obiektów). Research Papers of Wroclaw University of Economics. No 1010. 52-71

19. http://www.agenda21.waw.pl [access: 29.01.2016]

20. http://www.sas24.org [access: 29.01.2016] 